\title{
The Implementation of Learning Vocabulary Using Flashcard for Young Children Through Google Classroom
}

\author{
I Gusti Ayu Winda Yuliantari ${ }^{*}$, Ni Nyoman Padmadewi², I Gede Budasi ${ }^{3}$ \\ ${ }^{1,2,3}$ Ganesha University of Education, Singaraja, Indonesia
}

\section{A R T I C L E I N F O}

Article history:

Received August 07, 2021

Revised August 22, 202

Accepted November 17, 2021

Available online December 25, 2021

\section{Kata Kunci:}

Kosakata, Flashcard, Google

Classroom, Anak Kecil

\section{Keywords:}

Vocabulary, Flashcard, Google

Classroom, Young Children

DOI:

http://dx.doi.org/10.23887/jpbi.v9i $\underline{3.38289}$

\section{A B S T R A C T} implementation of flashcards in Google Classroom to teach vocabulary and analyze the advantages and disadvantages of flashcards in Google Classroom. This research is a case study with an English teacher in the fifth grade of elementary school. Data was collected using a list of observations and interview guides. The procedure for collecting data is conducting online observations in Google Classroom and conducting interviews with research subjects. The data collected was analyzed qualitatively with the analytical technique of Miles and Huberman. The results showed that there were four planning activities: checking the syllabus, determining the text or material to be taught, determining the teaching method, and preparing a lesson plan. Second, teachers do three stages in implementing flashcards in Google Classroom, namely Initial Activities, Core Activities, and Closing Activities. Third, the advantages of using flashcards in Google Classroom are motivating students to learn, avoiding boredom, building student interest, and helping students remember vocabulary according to pictures. This research implies that the use of flashcards to teach vocabulary using Google Classroom can positively impact students, especially young learners.

This is an open-access article under the CC BY-SA license. Copyright (C) 2021 by Author. Published by Universitas Pendidikan Ganesha.

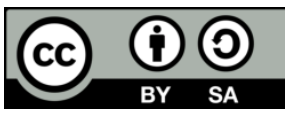

\section{INTRODUCTION}

As the covid-19 pandemic attack all countries in the world, it brings many impacts to the way of human life. It is a fact in the economic sector, health as well as the educational sector. Currently, this country is enforcing warnings, and restrictions to leave, work or go to school (Aji, 2020; Permai et al., 2021; Rafique et al., 2021). So that the mandate of many terms such as \#dirumahaja or doing activities from home such working and studying from home. Nowadays, many students learn from their homes in online learning flatform assisted by their parents. One of the most popular learning platforms in Indonesia is Google Classroom (Khalil, 2018; Mahitsa \& Mahardini, 2020; Setiawan \& Ari Oka, 2020). It has purposed to streamline the process of sharing files in education between teachers and students.it can assist the teacher to create material distributing material, and grading assignments (AlMaroof \& Al-Emran, 2018; Haka et al., 2020; Soni et al., 2018). Google Classroom is a tool used to communicate between students and teachers. In Google Classroom, teachers can assign a student with tasks and share materials. The teacher can create their class and share learning materials (Permata \& Bhakti, 2020; Suhery et al., 2020). Google Classroom is intended to help teachers and students to solve learning difficulties, teach lessons, and create assignments without attending class. Google Classroom, teachers can create active, student-centered, collaborative, and unforgettable learning as it provides easy-to-use learning features with students of all categories 
able to work together (Kurniawati et al., 2019; Kumar et al., 2020). Google Classroom is helpful for all grades of students from young learners to adults. Some advantages of Google Classroom are paperless, accessible anywhere as long as there is an internet connection and device assists teachers and students to communicate from distances, provide feedback to students, and personalized learning (Albashtawi et al., 2020; Guswara, 2020; Maharani \& Kartini, 2019). Google Classroom makes it easy for teachers to handle student work. It is very beneficial for teachers and students because it is easy to use. Google Classroom is also used in learning English.

English is a global language that is used and learned by everyone all around the world. English is an international language used to communicate with people from different countries (Permai et al., 2021; Sirivedin et al., 2018; Vonti \& Rahmah, 2019). It is also used to make International relations and to cooperate in various countries. It allows people to access world information quickly. English is used to communicate with many people in the world who have different languages and it is also beneficial for people to travel around the world (Andrade et al., 2014; Ho, 2020; Ling et al., 2014; Thoyyibah et al., 2019). Considering the importance of English, people from various countries start to learn it. English is considered a foreign language in Indonesia. It becomes a formal subject from elementary school to higher education level (Khusniyah \& Hakim, 2019; Saraswati et al., 2020; Trisnanti et al., 2018; Wahyudin et al., 2020). In learning a foreign language, Vocabulary is one of the essential things that must be considered. Vocabulary is very important in communication, not only in oral communication but also in written communication (Mahdi, 2018; Perez et al., 2013; Saeedakhtar et al., 2021). Learning vocabulary in a foreign language is an essential element to comprehend reading, writing, as well as speaking and listening (Rohmatillah, 2014; Zarei \& Afshar, 2014). Vocabulary refers to the words that people should know to communicate successfully, both in spoken and written form.

Vocabulary is an essential foundation for children's language development, affecting their study (Saeedakhtar et al., 2021; Tivnan, 2015). Thus, developing children's Vocabulary is critical to their learning (Chen \& Chan, 2019; Destiyanti et al., 2021). Vocabulary plays a great role in acquiring a language, and it is considered an essential aspect of children's language development (Alqahtani, 2015; Parvareshbar \& Ghoorchaei, 2016). Without having adequate Vocabulary, students will have difficulty learning a new language. The technique is using objects, drawing, using illustrations and pictures, contrast, expressions and gestures, and guessing from context (Alqahtani, 2015; Talebi \& Marzban, 2015). Flashcard is one media that illustrates vocabulary in form of the picture. Flashcard allows students to connect the meaning of new words with simple pictures (Chen \& Chan, 2019; Habibi, 2017). Flashcard is one of the media that can attract students' attention and encourage them to learn and be interested in English. Flashcard is an excellent tool for learning. Flashcard is considered to be a creative and fun way to help memory and retention of the vocabulary word. The use of flashcards in improving students' writing skills. This study found that flashcard was effective in improving students' writing skill and it could improve students' excitement (Anggraini et al., 2019; Ying et al., 2021). Previous research found that using flashcards as a visual learning medium was very useful in the teaching and learning process (Fidiyanti, 2020; Fitriyana et al., 2020; Putra et al., 2018; Trisnanti et al., 2018). It could stimulate students to understand the subject more effectively and efficiently. The research found that teaching vocabulary can improve students' vocabulary mastery (Hamer \& Rohimajaya, 2018). In addition, the use of flashcards can increase students' interest in learning and students enjoy learning more. Other research described how to develop flashcards and manual books as teaching media for teaching English vocabulary to young students in Singaraja (Taharyanti, 2017). The result of this study is that a well-developed flashcard can improve the quality of students' vocabulary learning. The results showed that the use of the flashcard-based instruction method gave the same impact on male and female students (Parvareshbar \& Ghoorchaei, 2016).

The previous studies concerned the use of flashcards in teaching vocabulary. That research was conducted in the offline learning setting. This recent research concerns the use of flashcards to teach vocabulary in the online learning setting. Google Classroom is one of the platforms used in online learning. Since teaching vocabulary is important for young children, a method to teach vocabulary online is needed. SD Fajar Harapan is a school that used Goggle Classroom to conduct online learning. Particularly in English subjects, the teacher used several ways to teach such as using media or using various teaching methods. Flashcard is one of the teaching media used by English teachers to teach vocabulary. Teaching vocabulary using flashcards is proven to be effective in the traditional classroom setting. However, since the covid-19 pandemic, educational activities are switched to online. The use of flashcards in the online classroom is rare to find. The English teacher commonly traditionally teaches vocabulary. Therefore, the purpose of this study is to analyze the use of flashcards to teach vocabulary to early childhood. Flashcard is implemented through Google Classroom as an online learning platform. Therefore, the title of this research is Implementation of Vocabulary Learning Using Flashcards in Early Childhood Through Google Classroom. 


\section{METHOD}

This research employed a case study design to find conclusions and answer the research problems. The case study is an in-depth study of one unit, such as one person, one group, one organization, one program, and so on. In addition, the aim is to provide a general description and a detailed understanding of the explanation to be solved (Ary et al., 2010). Cases are limited by time and operations, and researchers gather extensive information using a variety of data collection techniques over a long period. This research is qualitative in nature because it provides informative data in the form of written and oral data from the research subjects studied. Qualitative research is used to look for a phenomenon by focusing on the total picture rather than breaking it down into variables (Ary et al., 2010). By using this method, it was expected that this study could clearly describe the use of flashcards in teaching vocabulary through the online learning platforms starting from its planning, implementation, as well as the advantages and disadvantages.

This research was conducted at SD Fajar Harapan Bali. This school is a private school located in Badung, Bali. The school was selected under the consideration that the school includes English in its curriculum from grade one to grade six. Furthermore, English is used by the students when they communicate with the English teachers. The participants in this research were the English teacher and students of the fifth grade in SD Fajar Harapan. Thirty students in the class VA received English learning using flashcards through Google Classroom. This study used purposive sampling to select the sample. This study used observation and interviews to obtain in-depth information about these data. In this study, the process of analyzing the data is aimed to describe the qualitative implementation of the teaching English technique in Vocabulary for the fifth grade. The data analysis in qualitative research involves three things data reduction, data presentation/display, and conclusion drawing/verification (Huberman and Miles, 2012). In this study, the process of analyzing the data is aimed to describe the qualitative of implementation of the teaching English technique in Vocabulary for the fifth grade.

\section{RESULT AND DISCUSSION}

\section{Result}

Based on the questionnaire and interview with the English teachers, there were several activities which were done by teachers in preparing the activities in their classrooms. The activities were checking the syllabus, deciding the learning objectives, developing a lesson plan, and developing the flashcards were the activities done by teachers in the planning stage. After the teacher checked the syllabus, they developed the lesson plans. Based on the application of the teacher in teaching English using flashcards through Google Classroom. Teachers at Fajar Harapan Elementary School have prepared lesson plans that will be used when conducting bold learning sessions for children in Class V. After the teachers prepared the lesson plan, they prepared the flashcards. The teacher decided the vocabulary based on the learning material. Then, the flashcards were developed based on the vocabulary decided before. The flashcards were developed based on the topic. As stated by teacher 1: "Kind of thing that I prepared is, of course, the flashcard itself. I sometimes buy it in the bookstore and sometimes if the topic is quite hard, I make the flashcard by using simple design and paper". Based on except 2 the teacher prepared the flashcards before teaching. They sometimes get it in the book store or make it by themselves. "I matched the flashcard with the lesson plans that I used and also based on book package. I got from school or looked for other references from the internet". Based on except 3 the teacher matched the flashcards with the lesson plan to make the learning more integrated. Based on the data obtained from the results of interviews with the English teachers at SD Fajar Harapan who carry out English learning through the Google Classroom application, it can be seen that the implementation of learning English using online flashcards through Google Classroom is different to application in offline classes. The implementation was divided into three phases, namely pre-activity, whilstactivity, and post-activity. Before the actual implementation, the teacher created a Google Classroom for students. The teacher made a tutorial video that was shared with parents on how to use and join google classroom. The teacher assisted parents if they found difficulties in using Google Classroom. When the students are ready to use Google Classroom the teacher started the actual teaching based on their teaching schedule. The learning activity in Google Classroom implemented three phases, namely: pre-activity, whilst activity, and post-activity. Based on the data collection the teacher implemented a flashcard in four meetings.

In the first meeting, the teacher discusses Shopping Places. The vocabulary focus in this meeting is drug store, clothes shop, toy's shop, supermarket, butcher shop, mall, bookstore, and market. The teacher used Google Classroom as the Learning platform, flashcards, and video as the learning media. The learning activities were divided into three main phases, namely Pre activity, whilst activity, and post-activity. The teacher started the lesson by greeting the students and checking their attendance. After greeting and checking students' attendance the teacher gave perception to students by asking whether they have ever bought something. After giving an apperception the teacher confirmed the students' answers then followed by telling the learning materials, learning objectives, and learning activities in Google Classroom. The teacher applied Inquiry Based-Learning in this meeting. The teacher 
first posted a video and asked students to watch it by themselves. The teacher asked the question to students in the questioning stage. Next, in the investigation stage, the teacher showed flashcards to students and asked them to find out the word on each picture in the flashcard. The teacher was asked to put the answer in the comment column. After the teacher shared the video with the students, the teacher shared a flashcard about shopping places. The flashcards are market, meet shop, mall, supermarket, toy store, book store, flower shop, and stationary. Those flashcards were uploaded to Google Classroom by the teacher. The teacher named each picture by "picture 1", "picture 2", etc. the purpose to make students find the name of each picture by themselves. The students were asked to write their answers in the comment section. Later, the teacher confirmed the students' answers for each picture. After the teacher shared the flashcard and the students responded to it, the teacher assigned a task to write a short paragraph about a shopping place. In post-activity, the teacher did a reflection of today's meeting by asking what did the students feel after following the lesson. The teacher also reminds the students to collect their assignments on time.

The teacher used the Discovery Learning method to teach students. The topic in this meeting was the price of the thing. The focus of this meeting is a big number. The vocabulary was one thousand, two thousand, ten thousand, five thousand, twenty thousand, fifty thousand. The teacher used Google Classroom as the Learning platform, flashcards as the learning media. The learning activities are divided into three main phases, namely Pre activity, whilst activity, and post-activity. The teacher started the lesson by greeting the students and checking their attendance. After greeting and checking students' attendance the teacher gave perception to students by asking whether they have ever bought something. After giving an apperception the teacher confirmed the students' answers then followed by telling the learning materials, learning objectives, and learning activities in Google Classroom. During the whilst activity the students were asked to identify some flashcards of the price of things. Firstly, the teacher posted some pictures of money. Then the students were asked to write currency. The students were asked to post their answers in the comment sections. The below pictures show the flashcard posted by the teacher. After the teacher shared the flashcard and the students responded to it, the teacher assigned a task to write a conversation related to currency. In post-activity, the teacher did a reflection of today's meeting by asking what did the students feel after following the lesson. The teacher also reminds the students to collect their assignments on time.

In the third meeting, the teacher discussed Indoor sports. The teacher used Google Classroom as the Learning platform, flashcards as the learning media. The vocabulary being learn were badminton, volleyball, basketball, and hockey. The learning activities are divided into three main phases, namely Pre activity, whilst activity, and post-activity. The teacher started the lesson by greeting the students and checking their attendance. After greeting and checking students' attendance the teacher gave a short game to students by giving some pictures with incomplete words. After giving an apperception the teacher confirmed the students' answers then followed by telling the learning materials, learning objectives, and learning activities in Google Classroom. In the whilst activity the students were asked to mentions the sports that they like. They were asked to mention it in the comment section. After that, the students were asked to identify whether their favorite sport belong to indoor or outdoor sport. Then the teacher posted some pictures of indoor sports. Then the students were asked to read the text. The students were asked to read a task about sport. After reading, the students need to answer several questions related to the text. The below pictures show the flashcard posted by the teacher. After the teacher shared the flashcard and the students responded to it, the teacher assigned a task to answer the question related to sport. In post-activity, the teacher did a reflection of today's meeting by asking what did the students feel after following the lesson. The teacher also reminds the students to collect their assignments on time.

In the fourth meeting, the teacher discusses Sports. The focus of this meeting is sports outdoor. The vocabularies were cycling, football, running, and surfing. The teacher used Google Classroom as the Learning platform, flashcards as the learning media. The learning activities are divided into three main phases, namely Pre activity, whilst activity, and post-activity. The teacher started the lesson by greeting the students and checking their attendance. After greeting the students, the teacher told the learning material, learning objectives, and learning activities to students in Google Classroom. In the whilst activity the students were asked to mentions the sports that they like. They were asked to mention it in the comment section. After that, the students were asked to identify whether their favorite sport belong to indoor or outdoor sport. Then the teacher posted some pictures of indoor sports. Then the students were asked to read the text. The students were asked to read a task about sport. After reading, the students need to answer several questions related to the text. The below pictures show the flashcard posted by the teacher. After the students read fun facts, the teacher shared a flashcard and the students need to identify the flashcards. After the teacher shared the flashcard and the students responded to it, the teacher assigned a task to answer the question related to sport. In post-activity, the teacher did a reflection of today's meeting by asking what did the students feel after following the lesson. The teacher also reminds the students to collect their assignments on time.

In general, the step of implementing a flashcard in Google Classroom was done by three main stages, namely Pre activity, whilst activity, and post-activity. The teacher mostly implemented discovery learning. It can 
be seen from four meetings the teacher implemented discovery learning in three meetings and one meeting using inquiry-based learning. The use of flashcards was mostly found in simulation, data collection, and data processing stages in discovery learning. Meanwhile, in inquiry-based learning, the flashcard was found in the questioning and investigation phase. The teacher does pre-activity, whilst activity, and post-activity. The teacher used flashcards in all meetings. After the interview conducted with the English teacher, it was found that the teacher got some strengths and weaknesses in using Flashcard to teach vocabulary to the student. There are several strengths found by the teacher during teaching using flashcards as stated by the teacher. The strengths were described as follows. First, easy to understand. Using flashcards can help students to understand the material easily. Teachers perceived that students understand the material easily using flashcards. It was reported that students could answer more questions correctly after being taught using flashcards.

"The advantage of using flashcards from google classroom is that students have an easier time understanding the material being taught and it is easier to answer questions because there are already pictures that guide them to the purpose of the questions. And also, this flashcard is very interesting for students in the learning process".

Second, Interesting. Using flashcards can raise students' interest to learn. It was proven by the following excerpt. Flashcard was found to build students' interest and avoid boredom because flashcard contains pictures that can raise students' attention. Third, Saving costs. Using flashcards in Google Classroom can save costs because the teacher doesn't have to buy flashcards or print them. They can just share the picture in Google Classroom with the students. The excerpt showed that using flashcards in Google Classroom can save the cost of the teacher. This part describes the weaknesses of using Flashcards in google Classroom for Young Children. Based on the interview with the English teacher it was found that using flashcards brings some weaknesses. First, the students rely on the teacher. The students were not independent enough to find other vocabularies than what was taught by the teacher. It was proven by the following excerpt. "The weaknesses of using flashcards is the students didn't want to find another vocabulary because they just want to focus on the vocabulary flashcard". The teacher was afraid that students will not be independent to find other vocabularies in other resources because they just focused on vocabulary flashcards. It meant that students would not be independent enough to find information by themselves. Second, different levels of cognitive. The next weaknesses were some students could not follow the lesson well because of different levels of cognitive. Some students learn fast, while some others are left behind. It was hard to monitor students in Google Classroom. Third, the teacher needs more effort. Another weakness is teachers need more repot as they should be creative to make various flashcards with different topics. It makes the teacher needs more time to prepare the flashcards before teaching. Fourth, lack of internet connection. Online learning through LMS needs a sufficient internet connection. It would be a problem if the internet connection was low and the device was not available. The lack of internet connection has made the learning not effective. Besides it hindering the teacher to post the material or assignment, it also hinders students in responding to the teachers' question or instruction.

\section{Discussion}

The initial activities carried out, namely checking the syllabus, learning objectives, preparing lesson plans, and developing flashcards were activities carried out by the teacher at the planning stage. In planning the activities in Google Classroom, the teacher starts by checking the syllabus, making learning material, preparing flashcards and video as the media. Planning is a process of preparing a framework to guide the teacher in teaching (Abrams \& Byrd, 2016; Atmojo \& Nugroho, 2020; Nurlaily et al., 2019). In planning activity, teachers identify content, develop a timeline, identify goals, skills, and objectives, decide on instructional materials, decide on activities to employ, decide on tests and quizzes, and adjust instructional plans on a weekly or daily basis. there are eight types of planning. Six types are concerned with the period (weekly, daily, long-range, short-range, yearly, and term planning), and two describe a unit of content that teachers plan for (unit and lesson). Teachers need to notice the type of the vocabulary, the students' level, and characteristics, and also the value of the techniques for the learners (Luciana, 2020; Nurlaily et al., 2019).

The flashcards were used in whilst activity, they were used to introduce vocabulary to students. The teacher posted teacher flashcards then asked students to name the pictures. After the students name the pictures with their knowledge, the teacher confirmed the student's answers. Flashcards have an impact on students' ability to receive vocabulary in the learning process and increased the classroom atmosphere because the students were more enthusiastic (Chen \& Chan, 2019; Habibi, 2017; Taharyanti, 2017). By using the flashcard, the students were enthusiastic and can be managed because they were focused on the teacher when the teacher showed flashcards to them while mentioning the name of the picture of it. Using flashcards as a medium in teaching vocabulary was sufficient to improve students (Fidiyanti, 2020; Fitriyana et al., 2020; Kusumawati et al., 2017). There were several ways to teach vocabulary using flashcards, namely rhyme and lines flashcards, vocabulary introduction, find the pictures, story cards, categorizing vocabulary, and flashcard memory games. The students were able to make a 
good story because they were helped by the flashcards. Using flashcards make the students could imagine what the word looks like and it helps them to make a story related to it. Using flashcards in an online setting was found to be effective in teaching vocabulary. The research found that using flashcards by combining them with technology can improve students' vocabulary (Ying et al., 2021). Based on this research, students rely on visual resources to build word-image associations, and video and audio resources to learn the target language pronunciation. Using flashcards adapted to technology can help students to improve their learning outcomes (Habibi, 2017; Noge, 2019; Safitri et al., 2018; Ying et al., 2021).

Using Google Classroom to teach young children is proven to be effective. The research found that students could access the learning activities easily using this platform, they could communicate with other students in their subject electronically, they could decide when they wanted to learn, and they could work at their own pace (Amrina \& Sundari, 2021; Setiawan \& Ari Oka, 2020; Sibuea, 2018). Students experienced a sense of satisfaction and achievement and they felt at ease in working collaboratively with other students (Haka et al., 2020; Mahitsa \& Mahardini, 2020). It shows that learning vocabulary through Google Classroom can build students' independence from a young age. Using Google Classroom is very effective for students not only at young ages but also at a higher level of education. Google Classroom is effective to use for students in this online situation as it provides students with e-learning that can be attractive for the students, while the process of teacher learning moves to virtual classes (Okmawati, 2020; Soni et al., 2018). Other research found that there was a significant difference between students who learned English through Google Classroom in blended learning with students who learned in conventional classes (Hidayati et al., 2020). Students who learn in Google Classroom achieved a significantly higher score than those who learn in the conventional classroom. Learning through Google Classroom had contributed to the improvement of students' English ability.

Based on the interview, the teacher faces some weaknesses in using flashcards in Google Classroom. The weaknesses were the students' reliance on the teacher, different levels of cognitive, the teachers need more effort, and lack of internet connection (Permata \& Bhakti, 2020; Suhery et al., 2020). The teachers gained benefit by using google classroom (Kumar et al., 2020; Kurniawati et al., 2019; Suhroh \& Cahyono, 2020). However, the teacher found weaknesses such as internet connection and online submitted assignments. Lack of internet connection made the google classroom could not run well (Albashtawi et al., 2020; Guswara, 2020). In addition, it was hard to ask students to submit their tasks on time. Google classroom as a helpful tool to conduct virtual classroom, Findings showed that teachers use it as a facilitation tool for managing students' tasks, organizing the classroom, and accommodating students' interaction. There were some obstacles encountered during the learning process using Google classroom. The connection of the internet was not stable all the time and sometimes the tools to support this process were broken or did not work well, and it needed time to fix it which influenced the learning process. From the students' side, the students should have a laptop, or if they would like to use their smartphone, they should have credit to connect to the internet. The other issue is that not all of the teachers can adapt easily to technology. Because this is the new one, it is necessary to train and equip them with this skill so that they could teach confidently and comfortably and make the goal of teachings will be achieved.

\section{CONCLUSION}

Several things must be considered in planning flashcards in google classroom, namely syllabus, teaching material, teaching method, and lesson plan. There are three steps conducted by the teacher in Implementing flashcards in Google Classroom namely, Pre activity, Whist Activity, and Post Activity; the flashcard was used in whilst activity in introducing the vocabulary to students, giving a game, and giving the assignment. There are some strengths of teaching vocabulary using Flashcard in Google Classroom, namely: motivating students to learn, avoiding boredom, building students' interest to learn, and helping students remember vocabulary. On the other hand, there were several weaknesses such as lack of internet connection and unsuitable device owned by the teacher.

\section{REFERENCES}

Abrams, Z. I., \& Byrd, D. R. (2016). The effects of pre-task planning on L2 writing: Mind-mapping and chronological sequencing in a 1st-year German class. System, 63. https://doi.org/10.1016/j.system.2016.08.011.

Aji, R. H. S. (2020). Dampak Covid-19 pada Pendidikan di Indonesia: Sekolah, Keterampilan, dan Proses Pembelajaran $\square$ Dampak Covid-19 pada Pendidikan di Indonesia: Sekolah, Keterampilan, dan Proses Pembelajaran. Jurnal Sosial \& Budaya Syar-I, 5(1), 395-402. https://doi.org/10.15408/sjsbs.v7i5.15314. 
Al-Maroof, R. A. S., \& Al-Emran, M. (2018). Students Acceptance of Google Classroom: An Exploratory Study using PLS-SEM Approach. International Journal of Emerging Technologies in Learning (IJET), 13(06), 112-123. https://doi.org/10.3991/ijet.v13i06.8275.

Albashtawi, A., Ham Albashtawi, A. H., \& Bataineh, A. (2020). The effectiveness of google classroom among EFL students in Jordan: An innovative teaching and learning online platform. International Journal of Emerging Technologies in Learning, 15(11), 78-88. https://doi.org/10.3991/IJET.V15I11.12865.

Alqahtani. (2015). The importance of vocabulary in language learning and how to be taught. International Journal of Teaching and Education, III(3), 21-34. https://doi.org/10.20472/te.2015.3.3.002.

Amrina, R., \& Sundari, H. (2021). Learning from Home Environment: Academic Writing Course for EFL Undergraduates through Google Classroom Application. Studies in English Language and Education, 8(2), 710-725. https://doi.org/10.24815/siele.v8i2.18374.

Andrade, M. S., Evans, N. W., \& Hartshorn, K. J. (2014). Linguistic support for non-native English speakers: Higher education practices in the United States. Journal of Student Affairs Research and Practice, 51(2). https://doi.org/10.1515/jsarp-2014-0020.

Anggraini, R. D., Listyarini, I., \& Huda, C. (2019). Keefektifan Model Picture And Picture Berbantuan Media Flashcard Terhadap Keterampilan Menulis Karangan. IJEE (Indonesian Journal of English Education), 3(1), 37. https://doi.org/10.23887/ijee.v3i1.17282.

Ary, D., Jacobs, L. C., Sorensen, C., \& Razavieh, A. (2010). Introduction to Research in Education (8th ed.). Wadsworth.

Atmojo, A. E. P., \& Nugroho, A. (2020). EFL classes must go online! Teaching activities and challenges during COVID-19 pandemic in Indonesia. Register Journal, 13(1), 49-76. https://doi.org/10.18326/rgt.v13i1.49-76.

Chen, R. W., \& Chan, K. K. (2019). Using Augmented Reality Flashcards to Learn Vocabulary in Early Childhood Education. Journal of Educational Computing Research, 57(7), 1812-1831. https://doi.org/10.1177/0735633119854028.

Destiyanti, C., Amin, M., \& Putera, L. J. (2021). Gender-Based Analysis of Students' Ability in Answering Factual and Vocabulary-in-Context Questions of the TOEFL-Like Reading Comprehension Test. Palapa: Jurnal Studi Keislaman Dan Ilmu Pendidikan, 9(1). https://doi.org/10.36088/palapa.v9i1.926.

Fidiyanti, L. (2020). Penggunaan Media Pembelajaran Flashcard Untuk Meningkatkan Penguasaan Vocabulary Dengan Materi Narrative Teks. Journal of Education Action Research, 4(1), 44. https://doi.org/10.23887/jear.v4i1.23437.

Fitriyana, N., Ningsih, K., \& Panjaitan, R. G. P. (2020). Penerapan Model Pembelajaran Savi Berbantuan Media Flashcard Untuk Meningkatkan Aktivitas Dan Hasil Belajar. Edukasi: Jurnal Pendidikan. https://doi.org/10.31571/edukasi.v18i1.1667.

Guswara, A. M. (2020). The Contribution of Google Classroom Application and Motivation to The Learning Outcomes of Web Programming. Educational Technology, 4(4), 1-9. https://doi.org/10.23887/jet.v4i4.29896.

Habibi, N. (2017). The Use of Flashcards in Improving Vocabulary Mastery of Students with Disability. Inklusi Journal Of Disability Studies, 121. https://doi.org/10.14421/ijds.040203.

Haka, N. B., Anggita, L., Anggoro, B. S., \& Hamid, A. (2020). Pengaruh Blended Learning Berbantukan Google Classroom Terhadap Keterampilan Berpikir Kreatif Dan Kemandirian Belajar Peserta Didik. Edu Sains Jurnal Pendidikan Sains \& Matematika. https://doi.org/10.23971/eds.v8i1.1806.

Hamer, W., \& Rohimajaya, N. A. (2018). Using Flash Card as Instructional Media to Enrich the Students' Vocabulary Mastery in Learning English. Journal of English Language Studies, 3(2), 167. https://doi.org/10.30870/jels.v3i2.3875.

Hidayati, A. N., Dewi, N. S. N., Nurhaedin, E., \& Rosmala, D. (2020). The Effect of Google Classroom in Blended Learning on University Students English Ability. J-SHMIC: Journal of English for Academic, 7(1), 66-76. https://doi.org/10.25299/jshmic.2021.vol8(1).6216.

Ho, Y.-Y. C. (2020). Communicative language teaching and English as a foreign language undergraduates' communicative competence in Tourism English. Journal of Hospitality, Leisure, Sport \& Tourism Education, 27. https://doi.org/10.1016/j.jhlste.2020.100271.

Huberman, A., \& Miles, M. (2012). Understanding and Validity in Qualitative Research. In The Qualitative Researcher's Companion. https://doi.org/10.4135/9781412986274.n2.

Khalil, Z. M. (2018). EFL Students' Perceptions towards Using Google Docs and Google Classroom as Online Collaborative Tools in Learning Grammar. Applied Linguistics Research Journal, 2(2), 3348. https://doi.org/10.14744/alrj.2018.47955. 
Khusniyah, N. L., \& Hakim, L. (2019). Efektivitas Pembelajaran Berbasis Daring: Sebuah Bukti Pada Pembelajaran Bahasa Inggris. Jurnal Tatsqif, 17(1), 19-33. https://doi.org/10.20414/jtq.v17i1.667.

Kumar, J. A., Bervell, B., \& Osman, S. (2020). Google classroom : insights from Malaysian higher education students ' and instructors ', experiences. Education and Information Technologies, 25. https://doi.org/10.1007/s10639-020-10163-X.

Kurniawati, M., Santanapurba, H., \& Kusumawati, E. (2019). Penerapan Blended Learning Menggunakan Model Flipped Classroom Berbantuan Google Classroom Dalam Pembelajaran Matematika Smp. EDU-MAT: Jurnal Pendidikan Matematika, 7(1), 8-19. https://doi.org/10.20527/edumat.v7i1.6827.

Kusumawati, P., Sudirman, \& Kusuma, P. I. (2017). the Effect of Digital Flashcard on Students' Vocabulary Mastery of the Fourth Grade Students At Sd Negeri 1 \& 2 Paket Agung in the Academic Year 2016 / 2017. Jurnal Pendidikan Bahasa Inggris Undiksha, 5(2). https://doi.org/10.23887/jpbi.v5i2.13324.

Ling, G., Powers, D. E., \& Adler, R. M. (2014). Do TOEFL iBT® scores reflect improvement in Englishlanguage proficiency? Extending the TOEFL iBT validity argument. ETS Research Report Series, 1. https://doi.org/10.1002/ets2.12007.

Luciana, N. L. R. (2020). Teachers' Readiness in Inserting the 21 st Century Skills in the Lesson Plan in Teaching English. Jurnal Pendidikan Dan Pengajaran, 53(2), 168. https://doi.org/10.23887/jpp.v53i2.26406.

Maharani, N., \& Kartini, K. S. (2019). Penggunaan google classroom sebagai pengembangan kelas virtual dalam keterampilan pemecahan masalah topik kinematika pada mahasiswa jurusan sistem komputer. PENDIPA Journal of Science Education, 3(3), 167-173. https://doi.org/10.33369/pendipa.3.3.167173.

Mahdi, H. S. (2018). Effectiveness of Mobile Devices on Vocabulary Learning: A Meta-Analysis. Journal of Educational Computing Research, 56(1). https://doi.org/10.1177/0735633117698826.

Mahitsa, M., \& Mahardini, A. (2020). Analisis Situasi Penggunaan Google Classroom pada Pembelajaran Daring Fisika. Jurnal Pendidikan FIsika, VIII(2), 215-224. https://doi.org/10.24127/jpf.v8i2.3102 ANALISIS.

Noge, M. D. (2019). Penerapan Model Pembelajaran Bilingual Preview-Review Berbasis E-Flashcard Untuk Meningkatkan Aktivitas Dan Prestasi Belajar Bahasa Inggris Siswa SMP. Journal of Education Technology, 2(1), 13. https://doi.org/10.23887/jet.v2i1.13801.

Nurlaily, V. A., Soegiyanto, H., \& Usodo, B. (2019). Elementary school teacher's obstacles in the implementation of problem-based learning model in mathematics learning. Journal on Mathematics Education, 10(2), 229-238. https://doi.org/10.22342/jme.10.2.5386.229-238.

Okmawati, M. (2020). The Use of Google Classroom during Pandemic. Journal of English Language Teaching, 9(2), 438. https://doi.org/10.24036/jelt.v9i2.109293.

Parvareshbar, F., \& Ghoorchaei, B. (2016). The Effect of Using Short Stories on Vocabulary Learning of Iranian EFL Learners. Theory and Practice in Language Studies, 6(7), 1476. https://doi.org/10.17507/tpls.0607.20.

Perez, M. M., Noortgate, W. Van Den, \& Desmet, P. (2013). Captioned video for L2 listening and vocabulary learning: A meta-analysis. System, 41(3). https://doi.org/10.1016/j.system.2013.07.013.

Permai, B., Clement, S., \& Yunus, M. (2021). English Teaching Amidst the COVID-19 Pandemic : Teacher Issues and Challenges Community of Inquiry ( COL ). Malaysian Journal of Social Sciences and Humanities (MJSSH), 6(5), 103-116. https://doi.org/10.47405/mjssh.v6i5.797 Malaysian.

Permata, A., \& Bhakti, Y. B. (2020). Keefektifan Virtual Class dengan Google Classroom dalam Pembelajaran Fisika Dimasa Pandemi Covid-19. JIPFRI (Jurnal Inovasi Pendidikan Fisika Dan Riset Ilmiah), 4(1), 27-33. https://doi.org/10.30599/jipfri.v4i1.669.

Putra, I. N. A., Jampel, I. N., \& Sudatha, I. G. W. (2018). Pengembangan Multimedia Flashcard Untuk Meningkatkan Kemampuan Menyimak Di TK Negeri Pembina Singaraja. Edutech Undiksha, 6(1), 32. https://doi.org/10.23887/jeu.v6i1.20260.

Rafique, G. M., Mahmood, K., Warraich, N. F., \& Rehman, S. U. (2021). Readiness for Online Learning during COVID-19 pandemic: A survey of Pakistani LIS students. The Journal of Academic Librarianship, 47(3), 102346. https://doi.org/10.1016/j.acalib.2021.102346.

Rohmatillah. (2014). A Study On Students' Difficulties In Learning Vocabulary (Bachellors' Degree). Jurnal Raden Intan Lampung, 3(1), 69-86. https://doi.org/10.24042/ee-jtbi.v6i1.520.

Saeedakhtar, A., Haqju, R., \& Rouhi, A. (2021). The impact of collaborative listening to podcasts on high school learners' listening comprehension and vocabulary learning. System, 101. https://doi.org/10.1016/j.system.2021.102588.

Safitri, R. W., Primiani, C. N., \& Hartini, H. (2018). Pengembangan Media Flashcard Tematik Berbasis Permainan Tradisional Untuk Kelas IV Sub Tema Lingkungan Tempat Tinggalku. Pendidikan Dasar Dan Pembelajaran, 8(1), 11. https://doi.org/10.25273/pe.v8i1.1332. 
Saraswati, W., Budiman, M. A., \& Rahmawati, I. (2020). Pembelajaran Bahasa Inggris Di SD Negeri Petompon 01 Semarang. Jurnal Sekolah, 4(4). https://doi.org/10.24114/js.v4i4.20616.

Setiawan, I. M. D., \& Ari Oka, I. D. G. (2020). The Use of Audio-Visual Assisted Google Classroom for Mathematics Course. Journal of Education Technology, 4(3), 244. https://doi.org/10.23887/jet.v4i3.28529.

Sibuea, T. F. B. (2018). Students' Perceptions on the Use of Google Classroom To Support Blended Learning for the Pengantar Linguistik Umum Course. Lingua: Jurnal Ilmiah, 14(2), 49-63. https://doi.org/10.35962/lingua.v14i2.45.

Sirivedin, P., Soopunyo, W., Srisuantang, S., \& Wongsothorn, A. (2018). Effects of Facebook usage on English learning behavior of Thai English teachers. Kasetsart Journal of Social Sciences, 39(2). https://doi.org/10.1016/j.kjss.2018.03.007.

Soni, Hafid, Hayami, Fatma, Wenando, Amien, Fuad, Unik, \& Mukhtar. (2018). Optimalisasi Penggunaan Google Classroom, E-Learning \& Blended Learning sebagai Media Pembelajaran Bagi Guru dan Siswa di SMK Negeri 1 Bangkinang. Jurnal Pengabdian Untukmu Negeri, 21. https://doi.org/10.37859/jpumri.v2i1.361.

Suhery, S., Putra, T. J., \& Jasmalinda, J. (2020). Sosialisasi Penggunaan Aplikasi Zoom Meeting Dan Google Classroom Pada Guru Di Sdn 17 Mata Air Padang Selatan. Jurnal Inovasi Penelitian, 1(3), 129132. https://doi.org/10.47492/jip.v1i3.90.

Suhroh, F., \& Cahyono, B. Y. (2020). The Perspective of Indonesian Teachers on the Google Classroom Usage in Blended Teaching. Jurnal Pendidikan: Teori, Penelitian, Dan Pengembangan, 5(10), 1495-1502. https://doi.org/10.17977/jptpp.v5i10.14139.

Taharyanti, G. A. P. (2017). Developing Flashcards and the Manual Book for Teaching English Vocabulary for Young Learners in Singaraja. Journal of Psychology and Instructions, 1(2), 71. https://doi.org/10.23887/jpai.v1i2.10362.

Talebi, M., \& Marzban, A. (2015). The Effect of Teaching Critical Reading Strategies on Advanced Iranian EFL Learners' Vocabulary Retention. Theory and Practice in Language Studies, 5. https://doi.org/10.17507/tpls.0503.17.

Thoyyibah, N., Hartono, R., \& Bharati, D. A. L. (2019). The Implementation of Character Education in the English Teaching Learning Using 2013 Curriculum. English Education Journal, 9(2), 254-266. https://doi.org/10.15294/eej.v9i2.30058.

Tivnan, T. (2015). The Importance of Early Vocabulary for Literacy Achievement in High-Poverty Schools. Journal of Education for Students Placed at Risk, November 2008. https://doi.org/10.1080/10824660802427710.

Trisnanti, I. A. N. L., Tirtayani, L. A., \& Putra, I. K. A. (2018). Pengaruh Media Flashcard Bilingual Terhadap Kemampuan Kosakata Bahasa Inggris Permulaan Anak Kelompok B TK Gugus Mawa. Journal Pendidikan Anak Usia Dini Undiksha, 6(3), 346. https://doi.org/10.23887/paud.v6i1.15200.

Vonti, L. H., \& Rahmah, M. (2019). The use of Hybrid/Blended Learning in Understanding of English Structure Subject to Improve Students' Achievement and Their Digital Literacy. JHSS (Journal of Humanities and Social Studies), 03(02), 99-102. https://doi.org/10.33751/jhss.v3i2.1467.

Wahyudin, A. Y., Jepri, D., Simamora, M. W., Pratiwi, I. W., \& Rina, A. (2020). Penggunaan komik digital toondoo dalam pembelajaran Bahasa inggris tingkat Sekolah menengah. Jurnal of Social and Tevhnologi for Community Service, 1(1), 1-6. https://doi.org/10.33365/jta.v1i1.673.

Ying, Y., Marchelline, D., \& Wijaya, G. (2021). Using Technology-Flashcard to Encourage Students Learning Mandarin. Journal of Physics: Conference Series, 1764(1). https://doi.org/10.1088/17426596/1764/1/012138.

Zarei, A. A., \& Afshar, N. S. (2014). Multiple Intelligences As Predictors Of Reading Comprehension And Vocabulary Knowledge. Indonesian Journal Of Applied Linguistics, 4(1). https://doi.org/10.17509/ijal.v4i1.598. 